\title{
University of Lapland
}

This is a self-archived version of an original article. This version usually differs somewhat from the publisher's final version, if the self-archived version is the accepted author manuscript.

\section{Sociomateriality and Affect in Institutional Work}

Katila, Saija; Laine, Pikka-Maaria; Parkkari, Piritta Susanna

Published in:

Journal of Management Inquiry

DOI:

$10.1177 / 1056492617743591$

E-pub ahead of print: 01.12.2017

Document Version

Publisher's PDF, also known as Version of record

Citation for pulished version (APA):

Katila, S., Laine, P-M., \& Parkkari, P. S. (2017). Sociomateriality and Affect in Institutional Work: Constructing the Identity of Start-Up Entrepreneurs. Journal of Management Inquiry, 1-14.

https://doi.org/10.1177/1056492617743591 


\title{
Sociomateriality and Affect in Institutional Work: Constructing the Identity of Start-Up Entrepreneurs
}

Journal of Management Inquiry

2019, Vol. 28(3) 38I-394

(C) The Author(s) 2017

Article reuse guidelines:

sagepub.com/journals-permissions

DOI: 10.1।77/I0564926|774359|

journals.sagepub.com/home/jmi

(S)AGE

\author{
Saija Katila', Pikka-Maaria Laine ${ }^{2}$, and Piritta Parkkari ${ }^{2}$
}

\begin{abstract}
Identity construction as a form of institutional work has mainly been studied from discursive perspectives. We examine how the identity of start-up entrepreneurs is constructed within the sociomaterial setting of a major start-up and technology conference, to enhance institutionalization of start-up entrepreneurship. We draw from the theories of performative identity construction, sociomateriality, and affect. Our study contributes to research on institutional work by highlighting the sociomaterial and affective nature of identity construction as a form of institutional work. We demonstrate how the identity of start-up entrepreneurs is constructed as rock star, vital entrepreneur, and buddy in a start-up ecosystem. Furthermore, we present characteristics of sociomaterial agency that strengthen identification with the institution of start-up entrepreneurship: multisensority, temporal multidimensionality, and the dynamics of equality and exceptionality building. Our study also critically demonstrates how constructed identities tend to reinforce the link between entrepreneurship and masculinity.
\end{abstract}

\section{Keywords}

affect, identity, entrepreneurship, institutional work, sociomateriality

\section{Introduction}

I leave the pouring rain of a Nordic November behind me when entering the Great Exhibition Centre. The beat of the music hits me and resonates with my body. Laser lights cut the air in a black, cave-like setting. I feel the excitement of the audience intensifying with the beat of the music. Then the excitement is released and the audience explodes. I feel thrilled. (Field notes, Researcher 2)

I can feel the beat of the bass in my body. A large crowd constantly walks past and jostles me. I feel I'm getting lost in the enormous dark area filled with flashing lights and huge video screens with fancy video graphics. I we feel queasy-After a while, I'm caught up in the rhythm of the event and start enjoying the vertigo. It's like being at a carnival or rock festival. (Field notes, Researcher 3)

We have entered Slush, a major start-up and technology conference that has become an iconic event in the field of startup entrepreneurship in Finland. Our strong affective experiences led us to wonder how this conference is geared to enacting the institution of start-up entrepreneurship, which can be seen as an emerging institution of entrepreneurship throughout the Western business word. In this study, we examine how the identity of a start-up entrepreneur is constructed within the sociomaterial setting of a conference to enhance institutionalization of start-up entrepreneurship.
It has been acknowledged that identity construction affects institutions by creating an attachment between actors and institutions (Creed, Dejordy, \& Lok, 2010; Giorgi \& Palmisano, 2017; Lok, 2010; Tracey, 2016). It is part of institutional work, which is defined as "the purposive actions of individuals and organizations aimed at creating, maintaining and disrupting institutions" (Lawrence \& Suddaby, 2006, p. 215). Previous research on institutional identity construction has examined how agents provide identities for people to mobilize support for them and legitimate the institutions in question (Creed, Scully, \& Austin, 2002; Oakes, Townley, \& Cooper, 1998; Rao, Monin, \& Durand, 2003; Wry, Lounsbury, \& Glynn, 2011). Some studies (Creed et al., 2010; Giorgi \& Palmisano, 2017; Leung, Zietsma, \& Peredo, 2014) focus on individuals' own identity work in confronting the contradictions between "the various social identities, which pertain to them in the various milieu in which they live their lives" (Watson, 2008, p. 129). We attach our study to both of these perspectives to understand the agency for enacting start-up entrepreneurship as distributed

\footnotetext{
'Aalto University, Helsinki, Finland

${ }^{2}$ University of Lapland, Rovaniemi, Finland

\section{Corresponding Author:}

Pikka-Maaria Laine, University of Lapland, P.O. Box I22, FI-96I0I

Rovaniemi, Finland.

Email: pikka-maaria.laine@ulapland.fi
} 
among various parties (Hampel, Lawrence, \& Tracey, 2015; Lok, 2010; Tracey, 2016). The organizers of our case conference offered clues regarding the identity of start-up entrepreneurs to the participants by building the particular sociomaterial setting for the conference. However, the specific focus of our study on identity construction was guided especially by our own intensive affectual sensations, which were evoked by the sociomaterial setting of the conference (Edensor, 2015; Gherardi, 2017; Ringrose \& Renold, 2014) and the expectations concerning appropriate ways of being and doing we experienced during the Slush conference. Thus, we regard both the organizers and the conference participants as institutional workers who participate in constructing the identity of start-up entrepreneurs within the sociomaterial setting of the conference to institutionalize start-up entrepreneurship.

Previous studies have mostly focused on symbolic and discursive forms of institutional work both in studies of institutional identity construction and in examining institutional work more broadly (Hampel et al., 2015; Lawrence, Leca, \& Zilber, 2013). Thus, the agency for changing and sustaining an institution has mostly been ascribed to people. However, there is a rising stream of research that has also shed light on the role of materiality in institutional work (Jones \& Massa, 2013; Lawrence \& Dover, 2015; Monteiro \& Nicolini, 2015; Munir \& Phillips, 2005; Raviola \& Norbäck, 2013). These studies have shown how material artifacts contain institutional information and are used to perform institutional work. Nevertheless, little is known about the role of materiality in institutional identity construction. Our study aims to contribute to filling this gap. Theoretically, we draw from the performative identity theory (Butler, 1990, 1997) and the theoretical perspectives of sociomateriality (Barad, 2003; Orlikowski \& Scott, 2008; Suchman, 2007) and affect (Blackman \& Venn, 2010; Gherardi, 2017; Henriques, 2010; Massumi, 2002; Wetherell, 2012). According to performative identity theory, identity is constructed continuously in and through actions. These actions are performative, that is, they construct meanings and identification with the meanings. According to the theory of sociomateriality, human actions are always entangled and intertwined with materiality. Hence, various meanings and identification with them are continuously constructed in and through the sociomaterial entanglements of Slush. Furthermore, affects are also involved in creating meanings and identification with them, as they are embodied sensations invoked in and through sociomaterial entanglements. All in all, the theories of performative identity construction, sociomateriality, and affect enable us to examine the capability or agency of sociomaterial entanglements in attaching the individual to the institution. This notion is crucial for establishing a more sophisticated understanding of the characteristics of sociomaterial agency in identity construction as a form of institutional work.

Our study is based on ethnography of the start-up and technology conference Slush. It could be seen as an extreme case study (Eisenhardt, 1989; Pratt, Rockmann, \& Kaufmann, 2006) where the role of materiality in institutional identity work is emphasized. The data collected consist of field notes, video-recordings from a pitching competition, and documentary material. In our analysis, we focused on understanding how human actions and materiality were entangled and on the kind of meanings and affective sensations evoked by entanglements. We further analyzed the capacity of the sociomaterial entanglements and affective sensations to intensify the attachment of agents to the institution of startup entrepreneurship. To highlight the connection of human actions and materialities, we made use of narrative analysis (Polkinghorne, 1988), which also enables the reader to relive the story (Connelly \& Clandinin, 1990) and thereby experience some of the affective intensities prevalent in the field.

Our study contributes to research on institutional work by highlighting the sociomaterial and affective nature of identity construction as a form of institutional work. We demonstrate how the identity of a start-up entrepreneur is constructed to comprise rock star, vital entrepreneur, and buddy in a startup ecosystem. Furthermore, we present three characteristics of sociomaterial agency that strengthen identification with the institution of start-up entrepreneurship: multisensority, temporal multidimensionality, and the dynamics of equality and exceptionality building. Moreover, our focus on institutional identity work opens up room for critical analysis that has thus far been less apparent within institutional research (Lawrence, Suddaby, \& Leca, 2011). The study shows how the constructed identities tend to reinforce the link between entrepreneurship and masculinity rather than dismantle it.

Our article is structured as follows. First, we introduce the discussions around identity construction as a form of institutional work and also materiality and affectuality in institutional work. Then, we present our methodological choices and explicate our data construction and analysis processes. This will be followed by three narratives that elaborate our findings. Finally, we discuss our contributions to research on institutional work and offer suggestions for future study.

\section{Identity Construction as a Form of Institutional Work}

Institutional work draws from the understanding that institutions are sustained and changed in and through situated actions by actors, who are seen as reflexive, intentional, and capable (Lawrence \& Suddaby, 2006). It attempts to capture the reciprocal dynamics of structure and agency (Hampel et al., 2015; Lawrence et al., 2013). Extant studies have identified various forms of institutional work in and through which actors seek to enhance the legitimacy of existing institutions or appeal to new ones (for reviews of institutional work, see Hampel et al., 2015; Lawrence et al., 2013; Lawrence \& Suddaby, 2006). Identity construction has been acknowledged as a form of institutional work. It is seen to 
affect institutions by creating an attachment between actors and the focal institutional order (Creed et al., 2010; Giorgi \& Palmisano, 2017; Lok, 2010; Tracey, 2016).

Previous research on institutional identity construction has examined how identity is constructed for actors and audience alike to mobilize support around particular institutions (Creed et al., 2002; Oakes et al., 1998; Rao et al., 2003; Suddaby \& Greenwood, 2005; Wry et al., 2011). Creed et al. (2002), for example, examined how various parties constructed social identities in their legitimating accounts to enable account-makers and audiences alike to identify with the discourse and set of claims. Lately, studies have also turned to scrutinize how individuals engage in identity work to reconcile the contradictions experienced in the institutional field (Bévort \& Suddaby, 2016; Creed et al., 2010; Giorgi \& Palmisano, 2017; Leung et al., 2014; Lok, 2010; Tracey, 2016). Giorgi and Palmisano (2017), for example, demonstrated how members of mystic religious communities engaged in identity work to reconcile the contradictions between their creed and the Catholic Church. Tracey (2016), in turn, ascribed agency to both change agents and target individuals. First, he valorized the four types of institutional work used by the change agents of an evangelizing movement to convert the audience. In and through framing work, the message was legitimized by breaking down the generalized stereotypes of Christianity. Identity work, in turn, aimed at creating links between participants, change agents, and the "Christian family". Through affective work, emotions such as empathy and guilt were appealed to and performative work was accomplished by producing a theatrical spectacle and enabling participation in it. In addition, Tracey also ascribed the agency to target individuals by scrutinizing how they made sense of the messages of change agents.

As Tracey (2016) demonstrated, institutional work directs our attention to an agency that is not a heroic institutional entrepreneur, but more fragmented and distributed (see also, for example, Hampel et al., 2015; Lok, 2010; Raviola \& Norbäck, 2013). In our study, we see agency distributed within the sociomaterial practices of the Slush conference. Accordingly, we consider the organizers of Slush conference the creators of a sociomaterial setting that aim at influencing the audience. We also see the audience of the conference as institutional workers, as they, too, participate in constructing the identity of start-up entrepreneurs within the sociomaterial practices of Slush. Further, we recognize the contribution of materiality to institutional work. Previous studies on institutional work in general and institutional identity work in particular have mostly focused on discursive and symbolic forms of action (Hampel et al., 2015; Lawrence et al., 2013) and have thus ascribed agency to people. An emerging stream of studies has examined the role of materiality in institutional work (Jones \& Massa, 2013; Lawrence \& Dover, 2015; Monteiro \& Nicolini, 2015; Munir \& Phillips, 2005; Raviola $\&$ Norbäck, 2013). Most of these studies have illuminated how materiality enhances or restricts human agency. Raviola and Norbäck (2013) explicitly extend agency to materialities as well. Drawing on Callon's (2008) notion of agencement, they demonstrate how technology is involved in the decisions of journalists when they work to institutionalize new ways of enacting business online. However, there is a paucity of knowledge regarding sociomaterial agency in identity construction as a form of institutional work. We examine this through performative identity theory (Butler, 1990) and the theoretical perspectives of sociomateriality (Barad, 2003; Orlikowski \& Scott, 2008; Suchman, 2007) and affects (Blackman \& Venn, 2010; Henriques, 2010; Massumi, 2002; Wetherell, 2012).

\section{Performative Identity Theory and Institutional Identity Construction}

According to performative identity theory (Butler, 1990, 1997), identity is continuously constructed in and through linguistic and other bodily actions as people relate themselves to the issues at hand. When we study identity work from the perspective of performative identity theory, we see that it has three distinct characteristics in relation to a more general definition of identity work ${ }^{1}$ : Identity work is an ongoing accomplishment; identity work does not necessarily need to be triggered by acknowledged contradictions or threats in a milieu; and finally, in and through identity work, people cite existing (read: hegemonic and taken for granted) formations of knowledge and adjust them in the process of reiteration - mostly in subtle ways, but sometimes more subversively as well (Butler, 1990; Laine, Meriläinen, Tienari, \& Vaara, 2016).

Performative identity theory comports well with the theory on institutional work, which argues that

institutions are seen as ongoing human accomplishments, constructed and maintained by people's behaviour, thoughts and feelings, often in ways that are unreflexive and unintended, but just as often in ways that reflect people's awareness, their desires to affect institutional arrangements, and the skills and resources they marshal to achieve those desires. (Hampel et al., 2015)

Previous studies on institutional identity work have demonstrated how identity work can at times contain reflexivity in and through which actors gain new consciousness of self and enact new forms of identity, which may introduce change to institutional arrangements (Creed et al., 2010; Leung et al., 2014). However, the purposiveness of actions, which has been emphasized within institutional work, does not need to mean reflexivity; it can be seen to arise from habituated embodied tendencies that have been deposited in people through a continuous process of repetitive actions (Bourdieu, 1990; Butler, 1997; Chia \& Holt, 2006; Grosz, 1994). Thus, performative identity work assigns agency mostly by enacting institutions 
quite unreflexively and unintentionally. Still, as the actions are always indeterminate, there is a constant change going on in the process of repetition (Butler, 1990, 1997).

\section{Sociomateriality, Affect, and Institutional Identity Construction}

To highlight the distributed agency in the analysis of identity construction as institutional work, we also draw from the theorization of sociomateriality (Barad, 2003; Orlikowski \& Scott, 2008; Suchman, 2007) and affects (Blackman \& Venn, 2010; Henriques, 2010; Massumi, 2002; Wetherell, 2012). Sociomateriality does not privilege the agency of the social (the human) or the material, but rather assumes a position of constitutive entanglement of the social and the material (Orlikowski, 2007). Sociomateriality is a theoretical approach that has emerged in the areas of posthumanist practice theories (Gherardi, 2006; Nicolini, 2007), material feminism (Alaimo \& Hekman, 2008; Barad, 2003), science and technology studies (Suchman, 2007), and research on technology and organizations (Orlikowski \& Scott, 2008). To some extent, it may be seen as a counterforce to the linguistic turn, which overemphasizes the social by considering reality to be constructed in and through language. Sociomateriality posits that the social and material intra-act rather than merely interact. Intra-action rejects pregiven attributes and distinct agencies and suggests that subjects, objects, and agencies emerge in and through their encounters with one another (Barad, 2003; Suchman, 2007). Ontologically, this means that the social and the material are inseparable (Barad, 2003). By and large, sociomateriality adheres to a process ontology (Cooper, 2005; Nayak, 2008; Tsoukas \& Chia, 2002), as the social and the material come to exist in and through a continuous process of mutual constitution (Barad, 2003).

The social and material are embedded and entangled in practices, making all practices sociomaterial (Gherardi, 2001; Orlikowski, 2007). Affect, in turn, is an important ingredient of sociomaterial practices. While affect can be felt, it does not work through language, discourse, and meaning. It can be seen as the "excess to the practices of the 'speaking subject"' (Blackman \& Venn, 2010, p. 15) and as intensity, as energy that sets things in motion in us and across bodies, things (Massumi, 2002), and sociomaterial entanglements (Connolly, 2002, as cited in Idema, 2011, p. 64; Gherardi, 2017). Taking the affective bases of sociomaterial practices into consideration highlights the preverbal and nonconscious sensations of experience and their trans-subjective and intercorporeal nature. From this perspective, bodies are thoroughly entangled processes with the ability to affect and be affected (Blackman \& Venn, 2010; Pullen, Rhodes, \& Thanem, 2017). Contradictions, the importance of which has been emphasized as a trigger of identity work in general (Alvesson \& Willmott, 2002; Thomas \& Davies, 2005) and institutional identity work in particular (Creed et al., 2010; Giorgi \& Palmisano, 2017; Leung et al., 2014), also apparently emerge from quite unreflexive affective sensations invoked within sociomaterial entanglements (Edensor, 2015; Gherardi, 2017; Valtonen, Markuksela, \& Moisander, 2010). However, even though affects have been described as transpersonal or prepersonal intensities (Massumi, 2002), they are also sociohistorically oriented (Wetherell, 2012), which means, for example, that certain affects are anticipated, like the excitement in a football stadium (Edensor, 2015).

Sociomaterial entanglements are performative; they produce what they purport to name (Barad, 2003; Butler, 1990, 1993). Hence, we examine how sociomaterial entanglements and affective sensations invoked through them work in unison to construct an identity for start-up entrepreneurs and thereby enact start-up entrepreneurship.

\section{Method}

The empirical setting of the article is the Slush conference. It was founded in 2008 in Helsinki, Finland. It was apparently established as a yearly start-up event where Finnish entrepreneurs could meet each other, investors, and other businesses from Finland and abroad, and provide Finnish start-ups with visibility both nationally and internationally (Vesterinen, 2008). It was explicitly aimed at changing a state of affairs in which there were not many start-ups, where attitudes toward entrepreneurship were quite negative among students, and where there were few opportunities for start-up entrepreneurs to share experiences and meet with investors. The establishers wanted to create a cultural revolution (Auramo, 2014; Heinonen, 2016). The first few events were organized by local entrepreneurs, but in 2011, young ambitious students from local universities took over responsibility for organizing Slush (Heinonen, 2016; Hölttä, 2015). They wanted to add a "twist" to a technology conference and give it a rock festival feel, thus organizing a "one-of-a-kind technology festival" (Kuusi, 2015). They wished to make Slush a leading Nordic start-up event (Kuusi, 2015) that would attract international investors and media (O'Sullivan, 2015) and Helsinki the place for growth of entrepreneurship and technology communities (Teittinen, 2014). As the new organizing team took over, the number of participants attending Slush has increased 10-fold from 1,500 in 2011 to 15,000 in 2015 , and the number of investors has increased from four to 800 (Kuusi, 2015; O’Sullivan, 2015; www.slush.org). Slush has also arranged multiple events around the world, including Slush Asia in Tokyo, and plans to continue internationalization. Slush has gained increasing attention both in Finland and internationally. It has been recognized as a major event by technology-focused media such as Wired and TechCrunch.

Slush could be seen as an extreme case that is useful for theory building (Eisenhardt, 1989; Pratt et al., 2006). At Slush, space and the material setting play an essential part in 
making it a one-of-a-kind business conference. Thus, the role of materiality in identity construction as a form of institutional work is more pronounced than in other contexts, and the affective outcomes of the sociomaterial entanglements are easier to detect. To bring out the specificity of our case, we gathered three kinds of empirical material: ethnographic field notes, video-recordings from a pitching competition, and documentary material.

Our extensive field notes serve as the main source of material. They cover the two-day Slush conferences in 2014 (November 17-18, 2014) and 2015 (November 11-12, 2015) and include observations, photographs, short interviews with Slush conference participants, and videos. Two of the article's authors attended the conference in 2014 and all three participated in the 2015 event. When making the field notes, we paid special attention to the materiality of Slush (place, lights, screens, and stages) and the activities of the conference participants (speakers, hosts, judges, and audience). We also used both our own affectual experiences (Roberts, 2013) and our cultural understandings of entrepreneurship as sources of empirical material (Bell \& Davison, 2013; Coffey, 1999; Reed-Danahay, 1997). To be sensitive to the affective dimension of our experiences, we focused on the affective sensations of our own bodies through moving, smelling, feeling, seeing, tasting, and touching (Roberts, 2013). This enabled us to turn our attention from the explicit activities to the preverbal and unspeakable (Idema, 2011). We further used our cultural understandings of entrepreneurship to make sense of what we were seeing and experiencing. Our cultural understanding is based on our experiences as women and researchers of entrepreneurship. Furthermore, one of us is a consultant-entrepreneur and the other an activist in a student entrepreneurship society. Our bodies encompass understandings of the world in and through moving, feeling, seeing, smelling, hearing, touching, and tasting (Küpers, 2008; Merleau-Ponty, 1962; Strati, 1992, 2003), and this embodied understanding is social in the sense that it is shared by others.

Second, we used the video-recordings of pitches delivered at a "Slush 100" pitching competition in 2014. The competition included 100 pitches from the first round, 20 from the semifinals, and four from the finals (124 individual pitches altogether). These were all recorded, edited, and posted on YouTube by the conference organizers (https:// www.youtube.com/user/KickNetwork), and hence, the data were not produced by us or for the purpose of the research. We watched the videos both individually and collectively to get a sense of the pitching competition and pitching companies and, based on that, decided to make more detailed notes. We coded 27 pitches on an Excel sheet according to our coding scheme: From each video, we recorded the field of business/business idea, the market segment, the role of the presenter in the company, the gender, estimated age, nationality, race, build, dress, the kind of props used in the pitches, and the questions asked by the judges. One column was reserved for notes regarding deviations from the pitching format like "group presentation," "eye contact with jury, no contact to audience," "talks really fast-difficult to understand," "looks down," and "reads from papers." These data offered us a general understanding of the businesses, habitus of the performers, and the nature and quality of the pitching performances. We analyzed the pitches of the finalists in greater detail in regard to the embodied performances of the competing entrepreneurs and their relationship with the judges, the audience, and the material space and artifacts. We also have field notes and our own photographs and short video clips of the actual pitching situations and settings from all three rounds of pitching.

Finally, we also collected documentary material. This data set comprised online news articles and blog posts regarding Slush (both from Finland and internationally), the content on Slush's webpage (www.slush.org), and publicly available photos from Slush (https://www.flickr.com/photos/ slushmedia/). In particular, this extensive set covers the time before, during, and after Slush 2014 and 2015. This material offered us insight into the expectations and experiences of pitching competition judges and served as a background for understanding the history of the event and for placing Slush in its larger context.

The data analysis of our article followed an iterative process starting from the data and moving toward more theoretical arguments (Miles \& Huberman, 1994). First, we read the data and started coding for individual actions (what was done and how) and artifacts like presenting, announcing, greeting, competing, strobe lights, loudspeakers, and band. In the second round, we focused on how the coded actions and materiality were entangled and what kind of meanings and affective sensations they evoked. We further detected how bundles of sociomaterial entanglements formed larger practices. We identified three practices: festival making, pitching, and bonding. In the third round, we focused especially on the performative effects of the sociomaterial entanglements and practices, that is, on what kind of meanings, identities, and affective experiences they created and how they contributed to institutional identity work. While multiple meanings were produced within each practice, the core identities of rock star, vital entrepreneur, and buddy in a start-up ecosystem could be identified. In the fourth round of analysis, we focused our attention on understanding what contributed to the capacity of the sociomaterial entanglements to strengthen identification with the institution of start-up entrepreneurship. On the basis of our analysis, we identified three characteristics of agency: multisensority, temporal multidimensionality, and equality and exceptionality building. Even though we have presented a rather linear representation of our research process, coding and analysis were in fact entangled processes of becoming (Jackson \& Mazzei, 2012), where our affective connections to the data and the sense of wonder it created have also guided our analysis (MacLure, 2013). 
Rather than resorting to traditional ways of reporting qualitative research, we turned to narrative analysis where stories are written on the basis of collected data (Polkinghorne, 1988; Riessman, 2008). Narrative analysis resonated with our theoretical approach as narrative meanings emerge from the understanding that "something is part of some whole and that something is the cause of something else" (Polkinghorne, 1988, p. 6). Narratives connect human actions with material objects and events (Polkinghorne, 1988) and highlight the sense of movement through time (Gergen \& Gergen, 1986) making narrative analysis more than fitting for our purposes. Furthermore, narratives enable the reader to relive the story (Connelly \& Clandinin, 1990). Thus, our narrative attempts to evoke readers' affective sensations to experience even a small part of the affective intensity of Slush (Ellis \& Bochner, 2000; Schouten, 2014). The narratives explicate construction of a start-up entrepreneur identity in and through the sociomaterial entanglements and affective experiences of the conference. In the following, we present the narratives that highlight identity construction as a form of institutional work.

\section{Constructing the Identity of Start-Up Entrepreneurs}

\section{Festival Making}

We enter Slush. All natural light coming into the convention center through the large windows is blocked. Before we can even properly see what is ahead of us, we can feel the vibrations of the bass in our bodies. There are scaffolds throughout the space to give it a rough, industrial feel. Temporary, light-weight walls create pathways that lead the 14,000 participants around the huge open space. A large crowd of mostly cool-looking young people constantly walks past and jostles us in the enormous dark area. Loud electronic music, fog machines, flashing strobe lights, and lasers cut the air in the darkness, and the spectacular stages with huge video screens and fancy video graphics greet us as we make our way through the space. People move about to catch some of the ongoing events -100 companies competing with their pitches, 145 speakers, countless investor meetings, and bands playing at the parties. This is for all of us to enjoy. The intense rhythm of the bass and rapidly flashing lights accentuate the "fast forward mode" of Slush. You either keep up or risk missing something. Bombardment of all the senses with stimuli creates diverse affective experiences for us evoking queasiness, excitement, and a degree of puzzlement. After a while, we are caught up in the rhythm of the event and start enjoying the vertigo.

We all are here to meet each other and see the stars perform. Like in rock festivals, stars of varying intensity perform on different stages and the bigger the star, the bigger the stage. This time the stars are famous start-up heroes, prominent CEOs, investors, business angels, high-ranking civil servants, ministers, and presidents, whose embodied performances remain business-like. Slush is not only a venue for existing stars but also a place where stars are born in the pitching competition. The first round of 100 pitches take place on the small Yellow Stage. Performers talking into a hand-held microphone stand in front of three large TV-screens showing the name of the company. Only 20 contestants out of the 100 have sufficient (star) potential to continue to the semifinals. Although, during the first round of pitches, the audience is fairly small and the atmosphere remains rather intimate, the situation changes dramatically for the semifinals and finals. In the semifinals, contestants wearing wireless microphones face a larger audience on the Black Stage with its state-of-the-art technology and audiovisual effects. The 4-m high wall behind the presenter is covered with exquisite lights, and there is a large screen for slides and other visuals on the right side of the stage. A professional host enthusiastically presents each start-up company, and the audience plays a role in star-building by applauding and taking pictures of the presenters with their smart-phones.

In the finals, everything is BIG. The Silver Stage, where the finals happen, is raised a few meters above the floor and is roughly the size of one of the main stages of a rock festival. A futuristic video introduces the speaker followed by the speaker himself. There is a huge screen displaying a live video of the contestants and their slides. The stage is well-lit with spotlights on the performer and decorative neon lights at the back. Everyone has come to see the finals, which are the concluding program number of the conference. As the main stage area does not accommodate all the audience, the finals are also shown on the screens of the other conference stages indicating the importance of the moment. All the seats are taken and many people are standing to see the finalists perform. The contestants step onto the stage with a rhythm that resembles a rock concert rather than the composed and sedate entries of business talks. Some say "Whoa! What an audience!"; others wave or just start their pitch immediately. Three cameras follow the performing entrepreneurs. Audience members create a relationship with these stars by holding their smart-phones in the air to get good pictures and video clips of the finalists to be posted in social media.

There is electricity in the air as people await for the winner of the pitching competition to be announced. The jury is contemplating and we know the judges are in search of an " $\mathrm{X}$ factor" (www.slush.org). The jury's president comes on stage. He is middle-aged and looks like a businessman with his dark suit and white shirt, but he has left his tie at home. He holds a giant cardboard check in his hands. The media have already been reporting that the winner of the Slush 100 pitching competition will receive 250,000 euros in funding. Then, the president drops a bombshell: during the 2 days of Slush, he has pulled some strings, made dozens of phone calls, and had multiple conversations, and doubled the amount to be given the winner. Business angels from Finland, 
the Baltic, the Nordic countries, the United States, and Singapore have put more money into the pot. The audience gasps as he announces that the winner will receive 500,000 euros. The huge monetary prize coupled with the sociomaterial setting creates a feeling that entrepreneurship is about reaching for the stars where financial success awaits. For the few, this becomes a reality, but for the most, the fantasy is never realized.

As in music industry like the $\mathrm{X}$-factor, suspense is built before the winner is announced. An affective intensity is evoked by exited bodies; it is contagious and moves across the audience who wait in silent suspense. It focuses all our attention on the president of the jury on the stage. Our hearts are racing. The judges count "one, two, three ... and the winner is Enbrite.ly!" Lasers cut the air wildly after the announcement. The audience is shouting, whistling, and filming. This is the moment when stars are born. The finalists of the Slush 100 pitching competition are there for the huge audience to see and the media to report. Over 700 journalists attending Slush get to work, and practically, every newspaper and TV channel in Finland covers the finals. Slush at large receives a lot of international media attention. The contestants on the huge stage-with the flashing lights and the applauding audience-are like rock stars that everyone comes to see, admire, identify with, or criticize.

The practice of festival-making constructs an identity for the start-up entrepreneur as a rock star that stands out from the mass. The heroic rock star quality of the start-up entrepreneur is sociomaterially built up in the three rounds of pitching, where in each round, the size of the stage, the audiovisual system, the participating audience, and the media attention are enhanced with the increasing sophistication of speaker introductions and pitching performances. The way the sociomaterial entanglements are assembled in each pitching round produces increasing affective sensations to the participating audience, starting from rather modest sensations and reaching mass excitement before the winner is announced; all of this increases attachment to the exceptionality of the start-up stars. The rock star start-up entrepreneur identity is depicted as a fantasy for all; like in the X-factor competition, it is something that can be assumed overnight. However, while the identity of a start-up entrepreneur as a rock star appears new, it is mainly based on circulating old meanings connected to entrepreneurship as it reproduces meanings with masculine connotations like competitiveness, success, and heroism, but at an intensified level.

\section{Pitching}

The pitching competition is at the core of Slush. From over a thousand applicants, 100 are selected to pitch at Slush. From there, 20 make it to the semifinals and four to the finals, but only one can be the winner. The contestants pitch back-toback, with 5-min pauses only after batches of 10 to 20 pitches. There is a digital clock on each stage to show the minutes and seconds remaining for the contestant. The pitches themselves are short; only $3 \mathrm{~min}$ in the first round and $5 \mathrm{~min}$ in the consecutive rounds; in that short time span, you have to convince the judges even faster: "It's quite rough, in 30 seconds I have to get the feeling that this interests me," says Ilkka Kivimäki, one of the judges (Sirén, 2014). The ticking clock, changing presenters, fast talk, and quick questions create a sense of speed and efficiency.

Those progressing in the competition have practiced their pitches. They know what is expected of them. "They have to be able to crystallize their business idea and demonstrate how big it can grow in order to convince us," one of the judges explains. The contestants go beyond mundane problems when they promise to "fight online fraud," "bring ethics to incumbent industries," "reduce packaging waste," and "enable live online mentoring for programming." They are seeking technological solutions that can scale massively and solve global rather than local problems. They present precise figures in their pitches: growth in market size, paying customers, turnover, and number of downloads. However, growth potential and orientation are not sufficient to convince the judges. According to Riku Asikainen (the 2014 chairman of the board of Finnish Business Angels Network), "the final verdict is based on the how well the startup orchestra can play together" (Sirén, 2014). The presenters have to argue convincingly that their start-up team has the skills and experience necessary for success:

Our core team has experience in this field. We did everything from transactions to risk management to marketing so we are intimately familiar with these subjects. We actually built the in-house tools because we couldn't find any on the market to tackle these problems. (Enbrite.ly, semi-finals pitch).

A successful pitch constructs the vitality of the firm through multiplicity of meanings such as high-tech, great market potential, growth orientation, global scale, and team effort, in relation to materialities such as a ticking clock, fancy audiovisuals, and young - mainly male and able - bodies. In short, the companies selected as semifinalists and the finalist represented the current entrepreneurial ideal. Entrepreneurship is no longer about local owner-managers with modest growth ambitions. Instead, the viability of the firm is tied to the embodied pitching performance and the affectual sensations that construct the vitality of the entrepreneur.

Pitching competitions could be seen as "performance sports." The finals are the third pitching performance for the four finalists in 2 days. For them to make it from the initial pitching round to the semifinals and from there to the finals, they and their teams have to up the ante. Every pitch has to be better than the previous one. Between pitches, there are investor meetings, networking, partying, and not much time to sleep. The start-up entrepreneurs must demonstrate their endurance and the ability to improve quickly even under tremendous 
pressure. The Slush 100 competition is for the vital, not the weak. Everyone knows what is at stake. "We all want to get our voice heard, but there can only be one winner. To get to that magic check at the end of the day requires outshining everybody else," one of the judges explains (Sirén, 2014).

The entrepreneurs are there to give a perfect pitch, which is a tricky performance. "Although self-assurance is vital in taking the crowd, too much of it can backfire," as one of the judges puts it (Sirén, 2014). The comment illustrates that for the success of the pitch, the content, the material bodies of the performers, the audiovisuals, and the affective vibes they co-construct with the judges and the audience have to refer to the traditional ways of understanding business and behaving in business life. We focus our attention on one of the finalist's bodily performance. Although he speaks with a slight accent, his English is nearly perfect. He is smiling slightly and looks comfortable on stage. He doesn't move around much, but takes a few slow paces, stops, and paces again, facing different sides of the audience. He makes long relaxed eye contact with the audience. His gestures are discreet. At times, he opens his arms invitingly. The winner-to-be is now on stage for the finals. He is standing legs hip width with arms open to the side and palms facing upward. As the jury asks him detailed questions and challenges some of the points he had made, his gestures are restrained. His gestures create a sense of openness and trustworthiness. The (bodily) performances of the contestants coupled with the judges' comments produces a "business dance" where measured, open gestures are coupled with rational talk spoken in clear, natural cadences and without a trace of theatrical intonation. The bodily performances of the presenters produce a selfconfident, open and business-savvy image of the start-up entrepreneur. That is what the judges are looking for: "In the end it all boils down to a strategic mix of reliability and confidence" (Sirén, 2014). The affective experience has to meet the anticipations, at least to some extent.

The materiality of bodies is also relevant in another way. During the 2 days of pitching, we witness mainly young, white, male tech-specialists stepping onto the stage one after another in the "Slush uniform"- $\mathrm{t}$-shirt/hoodie, jeans, and sneakers. "I love your sneakers," a male judge remarks to one of the contestants during the finals as a sign of identification with the young male contestants. The only female entrepreneur pitching in the finals also receives her share of comments: "You look lovely as ever." It shows how little has changed in the ways women are positioned.

The pitching practice relies on the traditional practice of selling your business idea to the investors and customers, but it no longer takes place with Excel sheets and written business plans scattered around the office table. It happens quickly through embodied public performances where the affective sensations created become part of the selling process in addition to facts and numbers. In the performance, the vitality of entrepreneur and the firm become one. The number of companies participating in the Slush pitching competition further boosts the meanings of vitality. Those lacking vitality fall out of the competition by the numbers in the following sequence (1000-100-20-4-1). The practice of pitching further reproduces the connection between entrepreneurship and masculinity, and reduces the pool of suitable candidates by favoring young men. The visual and affective sensations created by young, able-bodied males taking the floor one after the other is a powerful factor in attaching the meaning of youth to the institution of start-up entrepreneurship.

\section{Bonding}

During the 2 days of Slush 2014, the 3,500 companies, 750 investors, and 14,000 participants make the best of the exceptional opportunity offered by the conference for networking. Some people come to Slush well prepared-there were nearly 3,800 prebooked meetings in 2014 (www.slush. org). This is nothing out of the ordinary at business conferences, but what is exceptional at Slush is the role of materiality in dismantling hierarchies to enhance equality in communication and opportunity. The entire Slush arena is designed to encourage networking; there are no VIP-areas, and the open exhibition areas, lounges, restaurants, cafes, and bars are used for discussions. Everyone is part of the same flow of people wearing the same big conference badges around their necks. In the darkness, it is difficult to make out the badges. A closer look reveals that people are assigned to one of the following categories: "start-up," "investor," "executive," "media," "student," and "conference." Furthermore, the beat of the bass and the flashing lights disturb the formality prevalent in business conferencing. The material setting encourages us to cross borders, but given that networking is not a Finnish forte, discursive encouragement is also given. During the conference days, Slush hosts advise participants to network by turning to each other and smiling or shaking hands. They even give advice on how to prepare for Slush in the Slush Survival Guide booklet distributed to the conference participants:

Pack plenty of business cards; Talk about Slush in advance. You never know who else is coming; Never skip lunch. Food brings people together; Go to the after-party, no matter how tired you are. Everyone will be there. Follow up with everyone you've met with nice, personal e-mails. Provide value, not just empty greetings. This is the point where acquaintances turn into valuable contacts.

It seems that people attending Slush do as advised.

While walking around the crowded spaces, we see many familiar faces from the media: CEOs of large companies, investors, and high-level politicians, even Prince Daniel of Sweden, greets one of us. Most of them are not here as keynote speakers, but as paying customers temporarily stripped of their hierarchical positions. For Slush, they are even 
dressed more casually than usual, thereby downplaying hierarchy. They are here for the pitches, the talks, and, of course, to network, just like us, but they are also here to be seen. If you have any serious interest in entrepreneurship and economic development in Finland, this is the place to be. Wherever we turn, mobile phones are taking pictures and videos and social media are flooded with Slush posts highlighting "I am here, where exciting things are happening." We bump into old friends and acquaintances. As we stop for a chat, we are introduced to new people. We get the feeling that Slush is not just about regular networking but something more intense-bonding.

Enthusiastic entrepreneurs and wannabe entrepreneurs seem to pitch to whoever is willing to listen. We witness an ad hoc pitch. Throughout the conference, a young Russian named Sergei (pseudonym) has been chatting to whoever will listen and pitching his team's business idea. Sergei stops a man and asks him if he could pitch their team's idea. The man stays and listens to Sergei's pitch. He gives Sergei some feedback and walks away. Sergei turns to the people close to him and says, "That was a nice man, who was he?" They laugh politely and tell him he's just pitched to the U.S. ambassador. We meet many people like Sergei during the conference and even have eager students come and pitch their ideas to us. A Japanese student tells about his experiences of Slush:

Here you can have a chat with co-founders, and business people. [It's] very different from Japan. This is very cool; it does not have to be so formal and business-like. I was so happy at Slush 2013 when I met Antti Mattila from Supercell [one of the world's leading mobile game companies] and he wanted to make an internship programme in Japan, and asked if I would like to join the programme. Now I am an intern at Supercell.

The bonding practice of Slush recites the traditional practice of networking of business conferencing, but the coming together of the dark shared space, proximity of bodies, similar badges, informal clothing, beat of the bass, flashing lights, and discursive encouragement to network creates an affective sense of community where people make themselves accessible beyond everyday networking. In so doing, they construct the identity of start-up ecosystem buddies for themselves as well for those with whom they are talking. For the duration of the conference, all identifying with the identity can feel included.

The intensive bonding does not end when the formal schedule is over, rather it is "taken up a notch." The evenings are there for partying together and continuing the discussions started during the day. There are official opening parties the night before Slush starts and afterparties on both days of the conference. The big official afterparty has gained something of a legendary reputation as stories about liters of free alcohol, crazy moments in the sauna, and Jacuzzi and general mayhem are spread around.
The main party is held at the same venue as the conference itself and the venue looks the same, but somehow different. The company booths are gone but the massive stages are still there. There are state-of-the-art stage lights and huge screens full of colorful videos flashing with loud, pumping music. The coolest pop and rock artists and DJs play on the stages until late at night. Open bars stocked with beer and cider have appeared and almost everyone walks around with a beer or cider can in hand. The whole area is turned into a huge party zone ripping off the last bits of formality linked to conferencing. Like during the official conference, there are no VIP lounges, no separate areas for special people. Students, startups, investors, executives, politicians, and volunteers mingle. Many seem to have found someone they wanted to meet, someone they were looking for. During the main party, one of us bonds with the chairman of the board of the Finnish Business Angels network, and the other with a famous venture capitalist to whom she pitches her business idea. She agrees on a business meeting with him the next day. Everything seems possible at Slush. The third bonds with no-one feeling that she does not belong in the space we are sharing.

The party is populated by young people, mainly men, accentuating the masculinity of the event. They show the older people how partying is done. The party is still going on at 2:00 a.m. and only the youngest one of us is still there. She hooks up with old and new friends on the dance floor, shouting and at times embracing the others. One young man even starts taking off his shirt. As she senses the movement, the heat and the smell of bodies next to hers, she feels she is truly part of the start-up scene.

The bonding practice of Slush is intensified through partying. In partying, different rules of interaction apply and the way the bonding practice is assembled in the evening further enhances the attachment of participants to the buddy identity in the start-up ecosystem. The bands; flashing lights; beer and cider cans; vibrating music; flashing videos; relaxed, alcohol-stimulated bodies; sweat and dancing; and touching bodies come together to create an affective sense of "we." The identity of a start-up entrepreneur constructed in the process is not that of a lonely wolf but rather that of buddy in a collective endeavor. Bonding in the bar or at the dance floor creates different kinds of connections than those created during the day. They are beyond formal connections and are thus easier to draw on in the future. Furthermore, the buddy identity of the start-up ecosystem enables individuals taking part in different entrepreneurial activities in start-ups, financing institutions, entrepreneurship societies, academic institutions, and support institutions to feel that they and their activities are part of a bigger whole, part of a social movement sweeping across Finland and beyond. They can feel they belong to this grand fantasy of an entrepreneurial future.

As we leave Slush, the sociomaterial assemblages dismantle and the affective intensities created disappear. The Cinderella moment is over. We all return to our ordinary 
selves and ordinary jobs. The start-ups get back to working hard on ideas that may never materialize, the CEOs and investment bankers return to their inaccessible corner offices, and the students get on with their studies. We stop smiling at each other and stop having conversations with strangers. However, after the conference, many of us carry at least a tiny bit of the experience of identifying with start-up entrepreneurs out to conquer the world. And for some, the process of becoming continues as the negotiations started with venture capitalists continue, sales and financing agreed during the conference are realized, and collaboration with new partners start. But for many, becoming a start-up entrepreneur remains a fantasized identity.

\section{Discussion and Conclusion}

Our study highlights the sociomaterial and affective nature of identity construction in enacting institutions. Identity construction as a form of institutional work has been studied mainly from discursive and symbolic perspectives (Creed et al., 2010; Creed et al., 2002; Lounsbury \& Glynn, 2001; Wry et al., 2011). We, however, build on the emerging stream of research that has scrutinized the role of materiality in institutional work. Materiality has been acknowledged to contain institutional information (Jones \& Massa, 2013; Raviola \& Norbäck, 2013), provide assistance (Monteiro \& Nicolini, 2015; Munir \& Phillips, 2005), or place obstacles to institutional work (Lawrence \& Dover, 2015). While Raviola and Norbäck (2013) have explicitly extended agency to materiality in institutional work, little is known about the role of materiality in identity construction as institutional work. Our study examined how the identity of the start-up entrepreneur is constructed within the sociomaterial practices of the start-up and technology conference Slush. We started by demonstrating how continuous actions - by organizers and participants entangled with materialities - create practices of festival making, pitching as well as bonding. In these practices, the continuous sociomaterial entangling creates meanings and affective sensations as well as identifications with these meanings and sensations. Hence, the identity of start-up entrepreneur is constructed to comprise rock star, vital entrepreneur, and buddy in the start-up ecosystem.

We argue that the capability of the sociomaterial entanglements - that is, agency - to generate identification with the institution of start-up entrepreneurship is intensified through three characteristics: multisensority, temporal multidimensionality, and the dynamics of equality and exceptionality building. Multisensority means that sociomaterial entanglements appeal to many senses at the same time: visual, audio, scent, taste, and haptic. This has been acknowledged to intensify the affectual sensations that stimulate attachment of the individual to the issues at hand (Edensor, 2015; Gherardi, 2017; Strati, 1992, 2003; Valtonen et al., 2010). Temporally multidimensional agency, in turn, refers to agential orientation to the past, present, and future (Battilana \& D'Aunno, 2009; Emirbayer \& Mische, 1998). Our argument about the temporally multidimensional agency of sociomaterial entanglements resonates with the study of Raviola and Norbäck (2013), who demonstrated how the present decisions of the journalists in relation to materialities were oriented both by past habits and future expectations. We show how identity construction in and through sociomaterial entanglements draws from the past while simultaneously reaching toward the future. However, we add affectual sensations as part of the sociomaterial entanglements, and also consider them to be sociohistorically oriented (Wetherell, 2012), even though they have been described as transpersonal or prepersonal intensities (Massumi, 2002). Hence, the capacity of affects - that is, agency - to generate identification with the institution also emerges by relating present experiences with both the past and future.

The dynamic of equality and exceptionality building is the third characteristic of the agency of sociomaterial entanglements and affective sensations. The dynamic exploits the basics of identity construction. First, as identity construction exploits the desire for existence, which is conferred from outside (Butler, 1997), we have a need to be part of a social group. This is accomplished through equality building. However, at the same time, we need to feel unique, because identity usually refers to meanings that are attached to people to create uniqueness and differentiation from others (Brown, 2015). In our material, the dynamic is created by backing up the exceptionality building of some conference participants with a simultaneous construction of equality among participants that promises exceptionality for everyone. In the following, we crystallize how the characteristics of sociomaterial entanglements and affective sensations - that is, multisensority, temporal multidimensionality, and dynamics equality and exceptionality building - catalyze identification with the institution of start-up entrepreneurship.

In the practice of festival making, multiple senses are bombarded with stimuli. The beat of the music, flashing lights in a dark, cave-like space, flowing masses of bodies, business talks, and the scent of a fog machine invoke affects that create a sense of fun, excitement, and energy for start-up entrepreneurship. Through these meanings, the sociomaterial entanglements and the affective sensations orient to the future. However, at the same time, they draw from the past by citing business conference practices such as business discourses, selection of keynote speakers, and the calm, business-like embodied performances of the presenters. The sociomaterial entanglements and affective sensations further build equality among the participants who join in to enjoy and identify with the energy and fun of the start-up scene. To some extent, this equality building is further constructed in the X-factor type of pitching competition, which is open for everyone and provides a promise of success for all. The 
increasing size of the stages, ever fancier audiovisual systems, increasing media attention, professional pitching performances, the filming and whistling audience, the proximity of exited bodies, the judges' questions, the tension created through music, the huge cardboard check, the final countdown, and the explosion of excitement into shouts, whistles, and applause when the winner is announced create affective intensity and collective subjectivity (Henriques, 2010); everyone is part of the star-building process and stardom could be for everybody. The affective power is tied to shifts in intensity of affects (Henriques, 2010) and the spread of affect across bodies in space (Massumi, 2002). The sociomaterial entanglements and affective sensations reach to the future by creating start-up idols who are conquering the world. However, at the same time, they draw from the past by accentuating old, masculinity-related meanings linked to start-up entrepreneurship such as competitiveness, success, heroism, and maleness (e.g., Anderson \& Warren, 2011; Essers \& Benchop, 2007; Hytti \& Heinonen, 2013).

Within the practice of pitching, sociomaterial entanglements and affective experiences create meanings of speed, effectiveness, and vitality. The affective experiences emerge especially through the entanglements of visual and audial sensations: the ticking clock, changing presenters, fast talk, slides, sales figures, young and able male bodies, excellent English, rapid-fire questions of the judges, and the embodied performances. The sociomaterial entanglements and the affective sensations orient to the future by disrupting the traditional mode of financial negotiations in the offices of investors by replacing them with embodied public performance and by linking the vitality of youth with start-up entrepreneurship. The young - and mostly male - bodies with open gestures, eye contact, and smiles promise to tackle global challenges, which invite us all to believe in the vitality of the start-up entrepreneur. However, the practice also draws from traditional business negotiations where credibility is built by presenting numbers and highlighting the competence of the team combined with the calm mode of the presentations (Garud, Schildt, \& Lant, 2014; Lounsbury \& Glynn, 2001). Lounsbury and Glynn (2001) reminded us that "the content of entrepreneurial stories must align with audience interests and normative beliefs to enable favourable interpretations of a new venture" (p. 550). Hence, identity construction through citing existing knowledge and ways of acting in the entrepreneurial world also provides a safe basis for identifying with the meanings of start-up entrepreneurship. The sociomaterial entanglements and affective sensations build the exceptionality of the "vital" entrepreneurs and set them apart from those 1,000 entrepreneurs attending the pitching competition who have fallen while trying.

Within the bonding practice, sociomaterial entanglements and affective sensations construct close and warm connections among strangers. A multiplicity of sensual experiences is created through dark shared space, proximity to celebrities and others, shaking hands, similar badges, informal clothing, the beat of the bass, flashing lights, bands, beer and cider cans, and the smell, heat, and touch of dancing bodies intensifying the affective sense of community. Although the sociomaterial entanglements and affective sensations orient to the past by reproducing business networking practices, the manner in which it is done orients to the future beyond formal relations toward something more intimate, that is, bonding. The sociomaterial entanglements and affective sensations build equality between the participants - all are allowed to share the same space, all are allowed to approach each other and feel included, and all are invited to engage in the shared excitement and fun.

All in all, we argue that, eventually, the dynamic of equality and exceptionality building strengthen start-up entrepreneurship by producing an ultimate fantasized identity that is continuously aspired to even though it will never be achieved. Part of the attraction of this ideal identity is based on the pull of fame and success created within the $\mathrm{X}$-factor type of competition and pitching practice, which culminates in the identities of the rock star and vital entrepreneur. The equality building, in turn, within the practice of bonding as well as the practice of festival making and openness of the X-factor type of competition back up the exceptionality building of few conference participants. Affective sensations play an important role in this process, as affect can subvert existing identifications and move us into new states of being (Massumi, 1996). However, for many, these identities of the rock star and vital entrepreneur are forever fantasized, rather than realized.

Finally, our study responds to calls to produce more critical readings of institutionalization processes (Lawrence et al., 2011). Our sociomaterial approach to identity construction as a form of institutional work has enabled us to highlight reproduction of masculinity in the institutionalization process of start-up entrepreneurship. Our findings demonstrate that by and large, while the start-up entrepreneur identities of rock star and vital entrepreneur reproduce dominant understandings of heroic (Anderson \& Warren, 2011; Essers \& Benchop, 2007; Hytti \& Heinonen, 2013) and masculine entrepreneurs (e.g., Ahl, 2004; Ogbor, 2000; Ozkazanc-Pan, 2014), they also accentuate them further. Also, linking entrepreneurship with Whiteness (Knight, 2006) and able-bodiedness (Kašperová \& Kitching, 2014) reproduces earlier understandings. Reproducing and institutionalizing these narrow understandings of entrepreneurship limits the pool of candidates who can identify and (credibly) assume the identity of a start-up entrepreneur, excluding women, non-Whites, people with disabilities, and those who are no longer perceived as young (see also Meriläinen, Tienari, \& Valtonen, 2015). It is noteworthy, however, that an identity depicting entrepreneurs as collective doers, buddies in the start-up ecosystem, is also emerging. The Slush event could be seen as a manifestation of this phenomenon. 
This study opens up interesting prospects for further research. First, it draws our attention to the sociomateriality of agency in institutional work, of which we still know very little. Our study suggests that adopting a sociomaterial and affectual approach would be useful for researching institutional work in general and institutional identity work in particular in any context.

\section{Acknowledgments}

We thank Professor Silvia Gherardi for introducing us to the discussion on affect.

\section{Declaration of Conflicting Interests}

The author(s) declared no potential conflicts of interest with respect to the research, authorship, and/or publication of this article.

\section{Funding}

The author(s) disclosed receipt of the following financial support for the research, authorship, and/or publication of this article: This work was supported by the Finnish Funding Agency for Technology and Innovation (grant number 40205/13) and the Foundation for Economic Education (grant number 3/1679).

\section{Note}

1. Identity work has been defined as actions in and through which people form, maintain, strengthen, diminish, or resist identities provided to them in their social milieu to achieve a sense of coherence and distinctiveness (Brown, 2015; Snow \& Anderson, 1987; Sveningsson \& Alvesson, 2003; Watson, 2008).

\section{References}

Ahl, H. (2004). The scientific reproduction of gender inequality: A discourse analysis of research texts on women's entrepreneurship. Malmö, Sweden: Liber.

Alaimo, S., \& Hekman, S. (Eds.). (2008). Material feminisms. Bloomington: Indiana University Press.

Alvesson, M., \& Willmott, H. (2002). Identity regulation as organizational control: Producing the appropriate individual. Journal of Management Studies, 39, 619-644.

Anderson, A. R., \& Warren, L. (2011). The entrepreneur as hero and jester: Enacting the entrepreneurial discourse. International Small Business Journal, 29, 589-609.

Auramo, H. (2014, November 8). Onko Slush nykyään yhtä hyvä kuin se oli vuonna 2008? [Is Slush nowadays as good as it was in 2008?] [Blog post]. Retrieved from https://www. linkedin.com/pulse/20141118134722-11581444-onko-slushnyky\%C3\%A4\%C3\%A4n-yht\%C3\%A4-hyv\%C3\%A4-kuinse-oli-vuonna-2008?trk=prof-post

Barad, K. (2003). Posthumanist performativity: Toward an understanding of how matter comes to matter. Signs, 28, 801-831.

Battilana, J., \& D'Aunno, T. (2009). Work and the paradox of embedded agency. In T. Lawrence, R. Suddaby, \& B. Leca (Eds.), Institutional work: Actors and agency in institutional studies of organization (pp. 31-58). Cambridge, UK: Cambridge University Press.
Bell, E., \& Davison, J. (2013). Visual management studies: Empirical and theoretical approaches. International Journal of Management Reviews, 15, 167-184.

Bévort, F., \& Suddaby, R. (2016). Scripting professional identities: How individuals make sense of contradictory institutional logics. Journal of Professions and Organization, 3, 17-38.

Blackman, L., \& Venn, C. (2010). Affect. Body \& Society, 16(1), 7-28.

Bourdieu, P. (1990). The logic of practice. Cambridge, UK: Polity Press.

Brown, A. (2015). Identities and identity work in organizations. International Journal of Management Reviews, 17, 20-40.

Butler, J. (1990). Gender trouble: Feminism and the subversion of identity. New York, NY: Routledge.

Butler, J. (1993). Bodies that matter: On the discursive limits of "sex." New York, NY: Routledge.

Butler, J. (1997). The psychic life of power. Stanford, CA: Stanford University Press.

Callon, M. (2008). Economic markets and the rise of interactive agencements: From prosthetic agencies to habilitated agencies. In T. Pinch \& R. Swedberg (Eds.), Living in a material world: Economic sociology meets science and technology studies (pp. 29-56). Cambridge, MA: MIT Press.

Chia, R., \& Holt, R. (2006). Strategy as practical coping: A Heideggerian perspective. Organization Studies, 27, 635-655.

Coffey, A. (1999). The ethnographic self: Fieldwork and the representation of identity. London, England: Sage.

Connelly, F. M., \& Clandinin, D. J. (1990). Stories of experience and narrative inquiry. Educational Researcher, 19(5), 2-14.

Cooper, R. (2005). Relationality. Organization Studies, 26, 16891710.

Creed, W. E. D., Dejordy, R., \& Lok, J. (2010). Being the change: Resolving institutional contradiction through identity work. Academy of Management Journal, 53, 1336-1364.

Creed, W. E. D., Scully, M. A., \& Austin, J. R. (2002). Clothes make the person? The tailoring of legitimating accounts and the social construction of identity. Organization Science, 13, 475-496.

Edensor, T. (2015). Producing atmospheres at the match: Fan cultures, commercialisation and mood management in English football. Emotion, Space and Society, 15, 82-89.

Eisenhardt, K. M. (1989). Building theories from case study research. Academy of Management Review, 14, 532-550.

Ellis, C., \& Bochner, A. (2000). Autoethnography, personal narrative, reflexivity: Researcher as subject. In N. Denzin \& Y. Lincoln (Eds.), Handbook of qualitative research (2nd ed., pp. 733-768). London, England: Sage.

Emirbayer, M., \& Mische, A. (1998). What is agency? American Journal of Sociology, 103, 281-317.

Essers, C., \& Benchop, Y. (2007). Enterprising identities: Female entrepreneurs of Moroccan or Turkish origin in the Netherlands. Organization Studies, 28, 49-69.

Garud, R., Schildt, H. A., \& Lant, T. K. (2014). Entrepreneurial storytelling, future expectations, and the paradox of legitimacy. Organization Science, 25, 1479-1492.

Gergen, K. J., \& Gergen, M. M. (1986). Narrative form and the construction of psychological science. In T. R. Sarbin (Ed.), Narrative psychology: The storied nature of human conduct (pp. 22-44). New York, NY: Praeger. 
Gherardi, S. (2001). From organizational learning to practice-based knowing. Human Relations, 54, 131-139.

Gherardi, S. (2006). Organizational knowledge: The texture of workplace learning. Oxford, UK: Blackwell.

Gherardi, S. (2017). One turn . . . and now another one: Do the turn to practice and the turn to affect have something in common? Management Learning, 48(3), 1-14.

Giorgi, S., \& Palmisano, S. (2017). Sober intoxication: Institutional contradictions and identity work in the everyday life of four religious communities in Italy. Organization Studies, 38, 795-819.

Grosz, E. (1994). Volatile bodies: Toward a corporeal feminism. Bloomington: Indiana University Press.

Hampel, C., Lawrence, T. B., \& Tracey, P. (2015). Institutional work: Taking stock and making it matter. In R. Greenwood, C. Oliver, T. B. Lawrence, \& R. Meyer (Eds.), SAGE handbook of organizational institutionalism (2nd ed., pp. 558-590). London, England: Sage.

Heinonen, J. (2016, November 29). Monella Slushin synnystä väärä käsitys - Kätilöinä markkinointiguru ja juristi [Many have wrong ideas about the conception of Slush: A marketing guru and an attorney were its midviwes]. Kauppalehti. Retrieved from https://www.kauppalehti.fi/uutiset/monellaslushin-synnysta-vaara-kasitys - katiloina-vesterbacka-ja-airisto/VazRYJbh

Henriques, J. (2010). The vibrations of affect and their propagation on a night out on Kingston's dancehall scene. Body \& Society, $16(1), 57-89$.

Hölttä, M. (2015, October 29). Myth busters. Aalto University School of Business News. Retrieved from http://biz.aalto.fi/fi/ current/news/2015-10-29-002/

Hytti, U., \& Heinonen, J. (2013). Heroic and humane entrepreneurs: Identity work in entrepreneurship education. Education + Training, 55, 886-898.

Idema, R. (2011). Discourse studies in the 21st century: A response to Mats Alvesson and Dan Kärreman's "decolonializing discourse." Human Relations, 64, 1163-1176.

Jackson, A. Y., \& Mazzei, L. A. (2012). Thinking with theory in qualitative research: Viewing data across multiple perspectives. London, England: Routledge.

Jones, C., \& Massa, F. G. (2013). From novel practice to consecrated exemplar: Unity Temple as a case of institutional evangelizing. Organization Studies, 34, 1099-1136.

Kašperová, E., \& Kitching, J. (2014). Embodying entrepreneurial identity. International Journal of Entrepreneurial Behaviour\& Research, 20, 438-452.

Knight, M. (2006). The production of the female entrepreneurial subject: A space of exclusion for women of color? Journal of Women, Politics \& Policy, 27, 151-159.

Küpers, W. (2008). Embodied "inter-learning"-An integral phenomenology of learning in and by organizations. The Learning Organization, 15, 388-408.

Kuusi, M. (2015, July 27). Miki Kuusi: "I've decided each Slush would be my last. But each time I've been left with a hunger for more." [Blog post]. Retrieved from https://www.aaltopro. fi/en/blog/miki-kuusi-ive-decided-each-slush-would-be-mylast-each-time-ive-been-left-hunger-more

Laine, P.-M., Meriläinen, S., Tienari, J., \& Vaara, E. (2016). Mastery, submission, and subversion: On the performative construction of strategist identity. Organization, 23, 505-524.
Lawrence, T. B., \& Dover, G. (2015). Place and institutional work: Creating housing for the hard-to-house. Administrative Science Quarterly, 60, 371-410.

Lawrence, T. B., Leca, B., \& Zilber, T. (2013). Institutional work: Current research, new directions and overlooked issues. Organization Studies, 34, 1023-1033.

Lawrence, T. B., \& Suddaby, R. (2006). Institutions and institutional work. In R. Stewart, S. R. Clegg, C. Hardy, T. B. Lawrence, \& W. R. Nord (Eds.), SAGE handbook of organization studies (2nd ed., pp. 215-254). London, England: Sage.

Lawrence, T. B., Suddaby, R., \& Leca, B. (2011). Institutional work: Refocusing institutional studies of organization. Journal of Management Inquiry, 20, 52-58.

Leung, A., Zietsma, C., \& Peredo, A. M. (2014). Emergent identity work and institutional change: The "quiet" revolution of Japanese middle-class housewives. Organization Studies, 35, 423-450.

Lok, J. (2010). Institutional logics as identity projects. Academy of Management Journal, 53, 1305-1335.

Lounsbury, M., \& Glynn, M. A. (2001). Cultural entrepreneurship: Stories, legitimacy, and the acquisition of resources. Strategic Management Journal, 22, 545-564.

MacLure, M. (2013). Classification or wonder? Coding as an analytic practice in qualitative research. In B. Coleman \& J. Ringrose (Eds.), Deleuze and research methodologies (pp. 164-183). Edinburgh, UK: Edinburgh University Press.

Massumi, B. (1996). The autonomy of affect. In P. Patton (Eds.), Deleuze: A critical reader (pp. 217-239). Oxford, UK: Blackwell.

Massumi, B. (2002). Parables for the virtual: Movement, affect, sensation. London, England: Duke University Press.

Meriläinen, S., Tienari, J., \& Valtonen, A. (2015). Headhunters and the "ideal" executive body. Organization, 22, 3-22.

Merleau-Ponty, M. (1962). Phenomenology of perception. New York, NY: Routledge \& Kegan Paul.

Miles, M. B., \& Huberman, A. M. (1994). Qualitative data analysis. Beverly Hills, CA: Sage.

Monteiro, P., \& Nicolini, D. (2015). Recovering materiality in institutional work: Prizes as an assemblage of human and material entities. Journal of Management Inquiry, 24, 61-81.

Munir, K., \& Phillips, N. (2005). The birth of the "Kodak moment": Institutional entrepreneurship and the adoption of new technologies. Organization Studies, 26, 1665-1687.

Nayak, A. (2008). On the way to theory: A processual Approach. Organization Studies, 29, 173-190.

Nicolini, D. (2007). Stretching out and expanding work practices in time and space: The case of telemedicine. Human Relations, 60, 899-920.

Oakes, L., Townley, B., \& Cooper, D. J. (1998). Business planning as pedagogy: Language and control in a changing institutional field. Administrative Science Quarterly, 43, 257-292.

Ogbor, J. (2000). Mythicizing and reification in entrepreneurial discourse: Ideology-critique of entrepreneurial studies. Journal of Management Studies, 37, 605-635.

Orlikowski, W. J. (2007). Sociomaterial practices: Exploring technology at work. Organization, 28, 1435-1448.

Orlikowski, W. J., \& Scott, S. (2008). Sociomateriality: Challenging the separation of technology, work and organization. The Academy of Management Annals, 2(1), 433-474. 
O'Sullivan, J. (2015). The startup spirit. Tekes Views Magazine 2015, pp. 6-9. Retrieved from http://www.tekes.fi/globalassets/ julkaisut/views_2015_magazine.pdf

Ozkazanc-Pan, B. (2014). Postcolonial feminist analysis of high-technology entrepreneuring. International Journal of Entrepreneurial Behaviour\& Research, 20, 155-172.

Polkinghorne, D. E. (1988). Narrative knowing and the human sciences. Albany: SUNY Press.

Pratt, M. G., Rockmann, K. W., \& Kaufmann, J. B. (2006). Constructing professional identity: The role of work and identity learning cycles in the customization of identity among medical residents. Academy of Management Journal, 49, 235-262.

Pullen, A., Rhodes, C., \& Thanem, T. (2017). Affective politics in gendered organizations: Affirmative notes on becomingwoman. Organization, 24, 105-123.

Rao, H., Monin, P., \& Durand, R. (2003). Institutional change in Toque Ville: Nouvelle cuisine as an identity movement in French gastronomy. American Journal of Sociology, 108, 795-843.

Raviola, E., \& Norbäck, M. (2013). Bringing technology and meaning into institutional work: Making news at an Italian business newspaper. Organization Studies, 34, 1171-1194.

Reed-Danahay, D. (Ed.). (1997). Auto/ethnography: Rewriting the self and the social. Oxford, UK: Berg.

Riessman, C. K. (2008). Narrative methods for the human sciences. Thousand Oaks, CA: SAGE.

Ringrose, J., \& Renold, E. (2014). “F**k rape!”: Exploring affective intensities in a feminist research assemblage. Qualitative Inquiry, 20, 772-780.

Roberts, R. A. (2013). How do we quote black and brown bodies? Critical reflections on theorizing and analyzing embodiments. Qualitative Inquiry, 19, 280-287.

Schouten, J. W. (2014). My improbable profession. Consumption Markets \& Culture, 17, 595-608.

Sirén, S. (2014, November, 19). Slush100: Do's and dont's in pitching. Retrieved from http://www.slush.org/2014/11/slush100-dos-donts-pitching/

Snow, D. A., \& Anderson, L. (1987). Identity work among the homeless: The verbal construction and avowal of personal identities. American Journal of Sociology, 92, 1336-1371.

Strati, A. (1992). Aesthetic understanding of organizational life. Academy of Management Review, 17, 568-581.
Strati, A. (2003). Knowing in practice: Aesthetic understanding and tacit knowledge. In D. Nicolini, S. Gherardi, \& D. Yanow (Eds.), Knowing in organizations: A practice-based approach (pp. 53-75). Armonk, NY: M.E. Sharpe.

Suchman, L. A. (2007). Human-machine reconfigurations: Plans and situated actions. Cambridge, UK: Cambridge University Press.

Suddaby, R., \& Greenwood, R. (2005). Rhetorical strategies of legitimacy. Administrative Science Quarterly, 50, 35-67.

Sveningsson, S., \& Alvesson, M. (2003). Managing managerial identities: Organizational fragmentation, discourse and identity struggle. Human Relations, 56, 1163-1193.

Teittinen, P. (2014, September 15). Euroviisut jäävät kakkoseksiSlushista Suomen historian suurin tekninen tuotanto [The Eurovision song contest will be left on second place-Slush to become the largest technical production in Finnish history]. Helsingin Sanomat. Retrieved from http://www.hs.fi/kulttuuri/ a1410748378250

Thomas, R., \& Davies, A. (2005). Theorizing the micro-politics of resistance: New public management and managerial identities in the UK public services. Organization Studies, 26, 683-706.

Tracey, P. (2016). Spreading the word: The microfoundations of institutional persuasion and conversion. Organization Science, 27, 989-1009.

Tsoukas, H., \& Chia, R. (2002). On organizational becoming: Rethinking organizational change. Organization Science, 13, 567-582.

Valtonen, A., Markuksela, V., \& Moisander, J. (2010). Doing sensory ethnography in consumer research. International Journal of Consumer Studies, 34, 375-380.

Vesterinen, V. (2008, September 22). Slush Helsinki [Blog post]. Retrieved from http://www.arcticstartup.com/article/slushhelsinki.

Watson, T. J. (2008). Managing identity: Identity work, personal predicaments and structural circumstances. Organization, 15, 121-143.

Wetherell, M. (2012). Affect and emotion: A new social science understanding. London, England: Sage.

Wry, T., Lounsbury, M., \& Glynn, M. A. (2011). Legitimating nascent collective identities: Coordinating cultural entrepreneurship. Organization Science, 22, 449-463. 